\title{
TRANSFORMASI BENTUK DAN FUNGSI KELUARGA \\ DI DESA MEKARWANGI
}

\author{
Imas Siti Patimah $^{1}$, Wahyu Gunawan ${ }^{2}$ \\ ${ }^{1}$ Pascasarjana FISIP Universitas Padjadjaran \\ imas18003@mail.unpad.ac.id
}

\begin{abstract}
ABSTRAK
Tujuan studi ini adalah untuk mengetahui transformasi atau perubahan bentuk dan fungsi keluarga di Desa Mekarwangi. Latar belakang penelitian ini yaitu terjadinya perpindahan atau mobilitas sementara dengan alasan mencari ilmu atau bekerja di tempat lain jauh meninggalkan desa. Metode penelitian yang digunakan adalah metode kualitatif dengan tekhnik pengumpulan data menggunakan observasi dan wawancara. Analisisnya menggunakan teori fungsional struktural dan teori interaksi simbolik. Temuannya menunjukkan bahwa bentuk dan fungsi keluarga mengalami perubahan namun tidak permanen. Kesimpulan studi ini menunjukkan bahwa terjadinya perubahan bentuk dan fungsi keluarga dalam masyarakat Desa Mekarwangi karena adanya perpindahan atau mobilitas sementara dari anggota keluarga, namun perubahannya bersifat sementara atau tidak permanent karena kuatnya ikatan kekerabatan dalam keluarga inti dan keluarga luasnya. Bentuk keluarga dapat saja berubah namun fungsi keluarga tidak berubah karena meskipun tidak tinggal dalam satu tempat yang sama namun fungsi kasih sayang, fungsi pendidikan, fungsi keagamaan dan fungsi ekonomi masih dapat dilaksanakan dengan interaksi jarak jauh menggunakan alat kominikasi yang sekarang sudah mudah dan cepat.
\end{abstract}

Kata kunci : Transformasi, Bentuk Keluarga, dan Fungsi Keluarga

\begin{abstract}
The purpose of this study is to determine the transformation or change in the shape and function of the family in Mekarwangi Village. The background of this research is the occurrence of temporary transfer or mobility on the grounds of seeking knowledge or working elsewhere far from the village. The research method used is a qualitative method with data collection techniques using observation and interviews. The analysis uses structural functional theory and symbolic interaction theory. His findings show that the shape and function of the family undergoes a change but is not permanent. The conclusion of this study shows that there is a change in the form and function of the family in the Mekarwangi Village community due to the temporary transfer or mobility of family members, but the changes are temporary or not permanent due to the strong ties of kinship in the nuclear family and extended family. The structure of the family may change but the function of the family does not change because even though they do not live in the same place, the function of love, education, religious and economic functions can still be carried out with long-distance interactions using communication tools which are now easy and fast
\end{abstract}

Keywords : Transformation, Family Form, Family Functions

\footnotetext{
2. Pascasarjana FISIP Universitas Padjadjaran wahyu.gunawan@unpad.ac.id
} 


\section{PENDAHULUAN}

Harta yang paling berharga, istana yang paling indah, puisi yang paling bermakna, dan mutiara tiada tara adalah keluarga. Itulah ungkapan dalam lagu soundtrack sebuah sinetron keluarga yang tayang di sebuah stasiun televisi beberapa waktu lalu dan bahkan sudah difilmkan. Keluarga adalah keberlangsungan umat manusia dari waktu ke waktu. Keluarga merupakan bagian terkecil dari masyarakat dan komunitas primer yang terpenting dalam masyarakat. Komunitas primer artinya suatu kelompok dengan kedekatan yang sangat erat antara anggota-anggotanya (Mansyur, 1999). Studi keluarga menjadi penting dalam beberapa tahun terakhir ini, sebagaimana terlihat dari minat para peneliti terhadap masalah keluarga. Data diperlukan tidak hanya untuk menggambarkan perubahan keluarga tetapi juga untuk memodelkan faktor penentu dan dinamika hubungan keluarga dari waktu ke waktu (Huinink, 2010) . Para peneliti studi keluarga menyadari adanya fenomena perubahan karakteriktik keluarga yaitu perubahan dari extended family menjadi nuclear family pada masa sekarang ini diakibatkan oleh beberapa faktor diantaranya keberhasilan keluarga berencana, perkembangan industrialisasi, emansipasi perempuan dan perubahan corak kehidupan ekonomi (Sutikno, 2014).

Studi tentang keluarga di beberapa negara diantaranya Inggris, Polandia, Norwegia, Austria, Amerika dan negara-negara Asia Tenggara termasuk Indonesia memfokuskan pada masalahmasalah keluarga dan dinamika hubungan keluarga serta perubahan tipe keluarga. Studi mengenai perilaku keluarga dan pernikahan menunjukkan adanya perubahan tersebut di semua negara di Eropa kecuali Albania. Masyarakat yang berbeda mengikuti lintasan perubahan yang serupa yaitu menuju pembentukan nuclear family, penundaan pernikahan, penurunan tingkat pernikahan, peningkatan hidup bersama yang belum menikah dan kemitraan non-perumahan serta peningkatan ketidakstabilan keluarga (Sobotka \& Toulemon, 2008). Fenomena tersebut merupakan pengaruh industrialisasi yang juga menimbulkan banyaknya anak yang lahir dari orang tua yang tidak menikah dan statusnya disamakan dengan anak-anak yang lahir dari orang tua yang menikah (Sobotka \& Toulemon, 2008): Hal ini menunjukkan adanya perubahan dalam sistem keluarga terutama pada keluarga pekerja yang tidak utuh yaitu terdiri dari ibu dan anak atau ayah dan anak saja.

Penelitian lain mengenai pernikahan yang berdampak pada perubahan fungsi keluarga adalah penelitian yang di lakukan di Inggris menunjukkan bahwa pernikahan tidak lagi diperlukan sebagai tampilan komitmen publik, tetapi sebagai acara simbolik (Berrington, Perelli-Harris, \& Trevena, 2015). Tidak heran apabila tingkat pernikahan menurun karena para perempuan lebih mementingkan karir pekerjaan dibandingkan dengan kehidupan keluarga. Modernisasi memang menimbulkan dampak yang sangat berarti terhadap keluarga dan dinamika hubungan 
keluarga. Hal ini berkaitan dengan dampak ekonomi pasar terhadap pernikahan dan keluarga, bahwa perkembangan kota dan industri telah mendorong banyak orang untuk mencari pekerjaan dan gaya hidup baru serta meninggalkan kebiasaan dalam kerangka adat pernikahan yang diatur oleh orang tua dan anggota keluarga yang berada di desanya(Zorn, 2010).

Lain halnya pada studi keluarga di Polandia, yaitu keluarga tetap merupakan nilai yang sangat penting dan tidak berubah selama periode 1990-2015. Penelitian tersebut menunjukkan bahwa wanita yang bekerja jauh dari rumahnya merupakan ibu jarak jauh untuk anak-anaknya yang juga disebut dengan matriarki manajerial (White, Grabowska, Kaczmarczyk, \& Slany, 2018). Fenomena tersebut tidak hanya terjadi di Polandia, di beberapa negara dimana para ibu yang bekerja jauh dari rumahnya termasuk penelitian di Norwegia, menunjukkan bahwa pembagian peran berdasarkan gender tidak menimbulkan ketegangan dan konflik(White et al., 2018). Hal tersebut menunjukkan bahwa di negara Polandia dan Norwegia, modernisasi dan perkembangan ekonomi pasar serta emansipasi perempuan tidak terlalu mempengaruhi keberlangsungan fungsi keluarga secara umum karena masyarakatnya masih memegang teguh nilai-nilai keluarga.

Dari beberapa penelitian yang dikemukakan di atas dapat dicermati adanya dua temuan dalam studi keluarga secara umum yaitu di satu sisi adanya perubahan keluarga disebabkan oleh modernisasi yaitu perkembangan industrialisasi dan emansipasi perempuan, disisi lain menunjukkan bahwa modernisasi tidak mempengaruhi perubahan keluarga. Dalam kenyataannya, perubahan yang terjadi tidak menunjukkan perubahan total dalam bentuk keluarga. Ibu atau ayah yang bekerja jauh dari rumah masih dapat mengontrol aktivitas rumah dengan alat komunikasi atau melalui kerabat yang dipercaya.

Studi-studi yang lain mengenai masalah keluarga diantanya kaitan antara faktor keluarga dengan kecemasan dan disorganisasi keluarga (Bögels \& Brechman-Toussaint, 2006; Nancy Foner et al, 2018; Soeradi, 2013). Studi tentang ekonomi keluarga yaitu keputusan pembelian dalam keluarga (Ekasasi, 2017) dan studi komunikasi keluargga wanita yang berpenghasilan lebih tinggi dari suami (Utami, 2017). Studi tentang fungsi keluarga yaitu fungsi afektif dan peran keluarga (Anita, 2015; Nasrudin, 2013; Rochaniningsih, 2014; Salviana \& Sugiarti, 1994). Studi tentang pengasuhan anak dalam extended family dan komunikasi keluarga (Utamidewi, Mulyana, \& Rizal, 2017; Yulion et al., 2013). Studi mengenai bentuk keluarga bukanlah kunci untuk digunakan dalam membentuk kebijakan sosial melainkan yang penting adalah pola interaksi dalam keluarga (Marotz-baden \& Adams, 2014) 
Studi-studi tersebut menunjukkan bahwa masalah keluarga dapat diatasi dengan mengatasi keseimbangan dalam menjalankan fungsi-fungsi keluarga. Beberapa studi keluarga yang telah dilakukan memberikan gambaran bahwa terdapat beberapa faktor yang berkaitan dengan keberlangsungan kehidupan keluarga diantaranya faktor dari dalam dan dari luar yang dapat mempengaruhi keluarga. Faktor dari dalam adalah adanya perubahan dari dalam keluarga itu sendiri yaitu perubahan struktur keluarga yang dapat mempengaruhi perubahan fungsi keluarga. Faktor dari luar diantaranya adanya pengaruh lingkungan (bencana alam), konflik dan peperangan.

Keluarga yang tinggal di Desa Mekarwangi sebagian besar merupakan keluarga inti yang terdiri dari ayah, ibu dan anak-anak dan juga terdapat keluarga luas yang menempati tempat tinggal relatif berdekatan. Keluarga luas terdiri dari kakek, nenek, ayah, ibu dan anak-anak. Kekerabatan pada keluarga masyarakat Desa Mekarwangi seperti pada umumnya kekerabatan pada masyarakat Sunda yang menganut sistem bilateral yaitu menarik garis keturunan dari pihak ayah dan ibu. Hal ini berkaitan kebiasaan dalam menentukan tempat tinggal sebelum menikah yaitu tidak ada aturan yang mengikat mengahruskan untuk tinggal di salah satu kerabat.

Peluang-peluang untuk meninggalkan desa dengan beberapa alasan diantaranya mencari ilmu (meneruskan sekolah ke jenjang yang lebih tinggi) karena di desa tersebut hanya sampai jenjang sekolah menengah pertama (SMP), mencari pengalaman karena ingin mendapatkan pengalaman yang lebih menantang, mencari peluang kerja di tempat lain karena di desa hanya berpeluang sebagai buruh tani dan menunaikan tugas sebagai pegawai negeri sipil. Perpindahan sebagian anggota keluarga tersebut dapat menimbulkan perubahan struktur dan fungsi dalam keluarga yang ditinggalkan. Studi ini bertujuan untuk mendeskripsikan perubahan keluarga yang terjadi akibat adanya alasan-alasan tersebut.

\section{METODE PENELITIAN}

Metode penelitian yang digunakan adalah metode kualitatif dengan tekhnik pengumpulan data menggunakan observasi dan wawancara. Studi ini merupakan studi kasus yang menggambarkan perubahan struktur keluarga yang terjadi pada masyarakat Mekarwangi. Observasi dilakukan dengan melakukan pengamatan pada lingkungan tempat tinggal masyarakat desa tersebut, selain itu juga mengamati lahan perkebunan yang merupakan tempat aktivitas ekonomi warga, mengamati sarana dan prasarana publik yang terdapat di desa tersebut. Wawancara dilakukan pada 27 responden yang berada di tempat tinggalnya maupun yang kebetulan masih berada di lahan perkebunan dimana mereka bekerja. Wawancara 
dilakukan dengan panduan pedoman wawancara yang telah disiapkan. Dari 27 responden terdiri dari 8 responden keluarga inti yang utuh (lengkap), 10 responden keluarga inti tidak lengkap, 4 responden keluarga luas lengkap dan 5 responden keluarga luas tidak lengkap.

\section{KERANGKA TEORI/KONSEP}

Dalam bagian ini diuraikan beberapa hal yang dapat menganalisis adanya perubahan yang terjadi dalam bentuk dan fungsi keluarga di Desa Mekarwangi diantaranya tipe-tipe keluarga, konsep keluarga, teori fungsional struktural dan teori interaksi simbolik.

\section{Perubahan Tipe Keluarga}

Studi tentang perubahan tipe keluarga pada abad ke 19 diwarnai dengan Damwinism (perubahan tradisional ke modern) yang memandang bahwa perubahan tumbuh melalui fase perkembangan yang sama dan menuju era yang sama yaitu sistem keluarga berkembang menuju pada bentuk yang sama yaitu monogami. Berbeda dengan pandangan Marxis yang menganut historical theory. Salah satu penganutnya adalah Engels yang mewakili paham radikal dengan konsepnya yaitu privatization of family (pandangannya sama dengan konservativisme). Frederic Le Play menolak otomixing effectt dari teknologi, industrialisasi dan pembagian kerja. Konsep Le Play mengenai 3 tipe dominan perubahan keluarga yaitu patriarchat (garis keturunan laki-laki), nuclear family dan stem family. Carla C. Zimmermen yang merupakan pendukung Le Play, mengemukakan tentang perubahan keluarga berdasarkan teori siklus yang membagi menjadi 3 tipe keluarga : Keluarga perwalian (trustee Family), Keluarga rumah tangga (domestic family), Keluarga terpisah (atomistic teori) : kekuasaan keluarga sampai dapat diambil alih oleh negara. Proses tersebut berulang, Fase modern sampai fase yang akan datang menujukkan adanya siklus atau disebut juga pengulangan fase(Ihromi, 1999).

Pendekatan konservatif dan radikal berbeda dengan pendekatan Chicago School of Sociology, studinya menanggulangi masalah yang terjadi akibat dampak perkembangan perkotaan dan memperkuat pranata keluarga. Chicago School mempengaruhi beberapa orientasi teoritis mengenai hilangnya fungsi keluarga sebagai akibat urbanisasi, tokohnya adalah William F Ogburn (1886-1956). Pandangannya tentang perubahan keluarga adalah hilangnya kebudayaan tradisional yang mengakibatkan munculnya tipe kehidupan keluarga yang baru yang lebih menekankan pada fungsi-fungsi kepribadian(Ihromi, 1999).

\section{Konsep Keluarga}

Keluarga merupakan satu-satunya lembaga sosial yang diberi tanggung jawab untuk mengubah organisme biologi menjadi manusia. Proses dalam mengubah organisme biologis menjadi organisme sosiologis membutuhkan keluarga sebagai agen. Tugas agen adalah mengenalkan 
dan memberikan pembelajaran mengenai prototype peran tingkah laku yang dikehendaki dan modus orientasi penyesuaian diri dengan yang dikehendaki (Rustina, 2014). Keluarga menurut Murdock adalah suatu grup sosial (kelompok sosial) yang dicirikan oleh tempat tinggal bersama, kerja sama dari dua jenis kelamin, paling kurang dua darinya atas dasar pernikahan dan satu atau lebih anak yang tinggal bersama mereka melakukan sosialisasi (Mansyur, 1999).

Burgess dan Locke mendefinisikan keluarga sebagai sekelompok orang yang disatukan oleh ikatan pernikahan, darah atau adopsi yang membentuk satu rumah tangga yang saling berinteraksi dalam peran sosial masing-masing suami dan istri, ibu dan ayah, saudara laki-laki dan perempuan saudari yang menciptakan budaya bersama (Burgess \& Locke, 1976). Definisi ini dapat dikatakan akurat dan komprehensif karena berlaku untuk mayoritas penduduk. Namun pada kondisi tertentu dimana suatu keluarga terdapat hambatan fisik untuk tinggal dalam satu rumah maka definisi tersebut menjadi tidak sesuai lagi. Bahkan penggunaan peran sosial seperti ibu, ayah, kakak dan saudara perempuan dapat meninggalkan celah untuk peran kekeluargaan yang diperpanjang sehingga membuat definisi ini kurang luas (Shukla, 2015).

Dari beberapa konsep keluarga di atas terdapat beberapa faktor yang menjadi ciri dari keluarga yaitu adanya pernikahan, melakukan interaksi dan komunikasi antar anggota keluarga, dan menciptakan budaya keluarga. Pernikahan dilakukan oleh laki-laki dan perempuan (bukan sesama jenis) karena berkaitan dengan keberlangsungan keturunan umat manusia yang menjadi salah satu tujuan berkeluarga. Interaksi dan komunikasi dalam keluarga merupakan ciri yang kedua dimana anggota keluarga melakukannya dengan intensif ataupun tidak intensif (bagi keluarga yang tinggal terpisah). Tidak semua keluarga dapat tinggal bersama dalam satu tempat, karena dalam suatu kondisi tertentu kadang beberapa anggota keluarga harus tinggal terpisah. Hal ini tidak menjadi masalah apabila komunikasi antar anggota keluarga dapat terjalin dengan baik. Beberapa studi mengenai masalah tersebut telah diungkapkan di atas.

\section{Tipe/Bentuk Keluarga}

Tipe atau bentuk dan struktur keluarga diantaranya : a. Keluarga inti (nuclear family) yang terdiri dari ayah, ibu, dan anak (hasil pernikahan atau adopsi); b. Keluarga besar (ekstended family) yaitu keluarga inti ditambah dengan sanak saudaranya (kakek, nenek, keponakan, paman, bibi, saudara sepupu, dan sebagainya); c. Keluarga bentukan kembali (dyadic family) yaitu keluarga baru yang terbentuk dari pasangan bercerai atau kehilangan pasangannya; d. Orang tua tunggal (single parent family) yaitu keluarga yang terdiri dari salah satu orang tua baik pria maupun wanita dengan anak-anaknya akibat perceraian atau ditinggal oleh pasangannya; e. Ibu dengan anak tanpa perkawinan (the unmarried teenage mother); f. Orang dewasa (laki-laki atau perempuan) yang 
tinggal sendiri tanpa pernah menikah (the single adult living alone); g. Keluarga dengan anak tanpa pernikahan sebelumnya (the nonmarital heterosexual cohabiting family) atau keluarga kabitas (cohabition); h. Keluarga berkomposisi (composite) yaitu keluarga yang perkawinannya berpoligami dan hidup secara bersama-sama (Fatimah, 2010).

Bentuk-bentuk keluarga di atas sesuai dengan perkembangan bentuk keluarga pada zaman sekarang dimana secara umum bentuk keluarga cenderung mengarah pada bentuk nuclear family (keluarga inti) terutama yang tinggal di perkotaan. Keluarga yang tinggal di kawasan pedesaan pun sudah jarang ditemukan bentuk keluarga luas (extended family) yang hidup dalam tempat tinggal yang sama. Dari beberapa studi keluarga menyimpulkan bahwa adanya fenomena tersebut merupakan dampak dari modernisasi. Aktivitas yang langsung berkaitan adalah aktivitas industri yang mendorong orang untuk bekerja di sektor industri dan meninggalkan tempat tinggalnya serta membentuk keluarga yang terpisah dari keluarga besarnya. Bnetuk keluarga yang ditelaah dalam penelitian ini terdiri dari 4 bentuk yaitu keluarga inti lengkap, keluarga inti tidak lengkap keliarga luas lengkap dan keluarga luas tidak lengkap.

\section{Fungsi Keluarga}

Beberapa fungsi keluarga diantaranya : fungsi keagamaan, fungsi sosial budaya, fungsi cinta dan kasih sayang, fungsi reproduksi, fungsi sosialisasi dan pendidikan, fungsi ekonomi, fungsi pembinaan lingkungan dan fungsi rekreasi (Wirdhana, I., et al, 2013) serta fungsi pemberian status. Fungsi keagamaan dan pendidikan merupakan faktor penting dalam keluarga dimana peran orang tua memberikan pendidikan keagamaan kepada anaknya sejak kecil. Sosialisasi merupakan sarana bagi pengenalan dasar-dasar keagamaan di lingkungan keluarga maupun di masyarakat, misalnya di tempat ibadah. Semua keluarga harus berusaha menjalankan fungsifungsi tersebut, terutama dalam hal ini tugas orang tua yang merupakan aktor utama dalam berfungsinya keluarga. Masalah-masalah keluarga timbul ketika salah satu atau beberapa fungsi tersebut tidak dijalankan. Hal ini pun berkaitan denga pengaruh modernisasi dan globalisasi yang terjadi pada masa sekarang.

\section{Teori Keluarga}

Beberapa teori di bawah ini merupakan teori makro dan teori mikro dalam sosiologi yang digunakan untuk menelaah masalah keluarga, diantaranya :

a) Teori struktural fungsional

Dalam mengaplikasikan teori struktural fungsional dalam keluarga tercermin dalam beberapa hal diantaranya berkaitan dengan : 1) Pola kedudukan dan peran dalam keluarga;

2) Peraturan berperilaku; 3) Tipe keluarga; 4) Aspek struktural; 5) Bentuk keluarga; dan 6) 
Struktur dalam keluarga. Institusi keluarga sebagai sistem kesatuan yang terdiri dari elemenelemen utama yang saling terkait: a) Status sosial; b) Fungsi dan peran sosial; serta c) Norma sosial (Puspitawati, 2013).

Teori struktural-fungsional menekankan pada keseimbangan sistem yang stabil dalam keluarga dan kestabilan sistem sosial dalam masyarakat Teori ini memandang bahwa semua aspek dalam keluarga harus berfungsi dan menunjukkan keseimbangan dalam keluarga. Keluarga yang baik adalah keluarga yang seluruh aspeknya berfungsi dan menunjukkan keseimbangan.

b) Teori interaksi simbolik

Teori interaksi simbolik merupakan salah satu teori keluarga yang terkait dengan ilmu psikologi dan komunikasi. Menurut pandangan psikologi sosial, terdapat dua hal yang sangat penting dalam keluarga, yaitu sosialisasi dan personalitas. Sosialisasi dalam keluarga menitik beratkan pada cara seseorang menerima sesuatu dan menerapkannya pada perilaku sesuai dengan pola, cara berfiikir, dan perasaaan masyarakat. Personalitas menitikberatkan pada sikap, nilai, dan perilaku yang telah diorganisir (Puspitawati, 2013).

Teori ini terfokus pada hubungan antara simbol (pemberian makna) dan interaksi (aksi verbal, non verbal, dan komunikasi). Teori ini memberikan sumbangan terhadap studi keluarga karena membahas keluarga sebagai kelompok sosial dan sekaligus membahas anggota keluarga sebagai individu yang mengembangkan konsep diri dan identitas melalui interaksi sosial.

\section{PEMBAHASAN}

\section{Proses Pembentukan dan Fungsi Keluarga}

Proses pembentukan keluarga di Desa Mekarwangi melalui proses pernikahan yang biasa dilakukan di desa dengan adat kebiasaan masyarakat pada umumnya yaitu melalui proses melamar atau meminang kemudian menentukan waktu pernikahan. Tata cara pernikahan menggunakan adat Sunda yang merupakan mayoritas masyarakat Desa Mekarwangi. Setelah menikah sebagian besar masyarakat memilih untuk tinggal di tempat kerabat istri yaitu di Desa Mekarwangi, namun ada kerabat suami yang merupakan penduduk Desa Mekarwangi memilih untuk tinggal menetap, dan ada juga yang memilih tempat yang baru. Sistem kekerabatan sebagian besar masyarakat menganut sistem kekerabatan bilateral yaitu menarik garis keturunan dari pihak ayah dan pihak ibu namun ikatan kekerabatan lebih kuat dengan kerabat perempuan dibanding laki-laki. 
Pendidikan informal teutama pendidikan keagamaan yang dilaksanakan dalam keluarga pada masyarakat Mekarwangi tidak mengalami perubahan karena masyarakat memegang teguh aturan dan prinsip agama yang sebagian besar menganut agama Islam. Orang tua (ayah dan ibu) bekerja sama menanamkan pendidikan keagamaan pada anak di rumah, terutama mengingatkan dan mengajak melakukan ibadah sholat. Keberadaan Madrasah dan TPA pun membantu orang tua khususnya bagi orang tua yang bekerja pada pagi hingga siang hari, sehingga pendidikan agama bagi anak mereka tidak terbengkalai. Beberapa keluarga menyekolahkan anaknya ke pesantren yang jauh dari desa demi pendidikan agama yang diharapkan oleh mereka untuk anaknya. Pendidikan agama memang merupakan prioritas utama dalam keluarga pada masyarakat Desa Mekarwangi sehingga pada beberapa keluarga pendidikan yang diberikan dalam keluarga adalah pendidikan agama. Dalam hal ini fungsi keagamaan dengan fungsi pendidikan merupakan dua hal yang tidak dapat dipisahkan dalam pengaplikasian fungsi dalam keluarga. Kedua fungsi tersebut sama sekali tidak ada perubahan dalam keluarga di Desa Mekarwangi, meskipun di beberapa tempat kedua fungsi tersebut mengalami perubahan fungsi karena pengaruh modernisasi dan globalisasi.

Fungsi reproduksi merupakan salah satu tujuan pernikahan dimana dua orang menikah mempunyai tujuan untuk melanjutkan keturunan. Fungsi tersebut diatur dengan adanya program keluarga berencana sehingga kelahiran anak dapat diatur supaya mendapatkan generasi keturunan yang berkualitas. Sebagian para ibu di Desa Mekarwangi menjadi Akseptor KB aktif dimana mereka melakukan pengaturan dalam kehamilan dan mempunyai anak tidak lebih dari dua anak seperti anjuran pemerintah. Tidak ada perubahan dalam melaksanakan fungsi tersebut karena sebagian besar keluarga masih mengharapkan kehadiran anak sebagai pelanjut keturunanya. Hal ini mungkin berbeda dengan perkembangan keluarga di negaranegara Eropa dimana para perempuan sudah tidak mau hamil dan melahirkan anak karena akan membuat fisiknya menjadi berubah.

Fungsi afeksi (kasih sayang) diantara anggota keluarga ditunjukkan dengan memberikan perhatian antar anggota keluarga baik secara langsung maupun tidak langsung. Hal ini biasa dilakukan dalam keluarga di Desa Mekarwangi dengan melakukan komunikasi yang intensif antara suami dan istri, anak dan orang tua, serta anak dan anak yang lain. Hal ini terwujud karena sebagian besar keluarga tinggal bersama dalam satu rumah sehingga interaksi dan komunikasi dilakukan secara intensif setiap hari dan setiap waktu. Pada keluarga yang salah satu anggota keluarganya jauh maka komunikasi dilakukan melalui alat komunikasi. Tidak ada perubahan dalam fungsi afeksi karena anggota keluarga yang tidak tinggal di rumah dapat 
berkomunikasi jarak jauh sehingga hubungan keluarga tetap dapat dilakukan meskipun tidak tingggal serumah.

Fungsi pendidikan pada anak dilakukan dalam keluarga sekaligus menjalankan fungsi sosialisasi, keagamaan, sosial budaya dan pembinaan lingkungan. Dalam keluarga ditanamkan nilai dan norma budaya yang berlaku dalam lingkungan masyarakat. Tanggung jawab pendidikan yang perlu diperhatikan oleh kedua orang tua terhadap anak ada tiga, yaitu: memelihara dan membesarkannya; mendidiknya dengan berbagai ilmu pengetahuan dan keterampilan yang berguna bagi hidupnya; dan membahagiakan anak untuk dunia dan akhirat dengan memberinya pendidikan agama (Mizal, 2014). Dalam aplikasi fungsi pendidikan formal, pada beberapa keluarga berusaha untuk menyekolahkan anaknya ke jenjang paling tinggi yaitu Perguruan tinggi. Fasilitas pendidikan formal di Desa Mekarwangi hanya sampai Sekolah Menengah Pertama sehingga untuk dapat bersekolah ke jenjang Sekolah Menengah Atas (SMA) harus meninggalkan desa. Demikian pula bila akan melanjutkan ke perguruan tinggi, mereka harus rela berpisah dengan anak-anak mereka untuk sementara waktu guna tercapainya cita-cita anak-anak mereka. Berdasarkan keterangan dari Desa, belum banyak penduduk Desa Mekarwangi yang melanjutkan ke pergutuan tinggi. Hal ini berkaitan dengan perkembangan ekonomi keluarga.

Dalam memenuhi fungsi ekonomi keluarga, para suami bekerja di perkebunan dan istri membantu suami dalam aktivitas tersebut bahkan tidak hanya bekerja pada lahan sendiri tetapi juga bekerja pada lahan orang lain. Hal inilah yang menunjukkan bahwa perempuan di Desa Mekarwangi berperan dalam membantu memenuhi ekonomi keluarganya sebagai buruh tani, meskipun upah yang diterima buruh tani perempuan lebih sedikit dibandingkan dengan yang diterima kaum laki-laki dengan beban waktu bekerja yang sama dan bahkan kadang dengan beban kerja yang sejenis. Dalam hal ini fungsi ekonomi keluarga pada masyarakat Desa Mekarwangi tidak berubah karena suami atau kepala keluarga masih melakukan tugasnya menjadi tulang punggung ekonomi keluarga dan dibantu dengan peran serta istri dalam memenuhi kebutuhan ekonomi keluarga. Meskipun pada beberapa kasus terdapat kepala keluarga yang bekerja jauh dari desa dan tidak tinggal bersama di rumah namun perannya dalam keluarga tetap sebagai penaggung jawab ekonomi keluarga.

Fungsi perlindungan dilakukan secara langsung dan tidak langsung yaitu melakukan komunikasi langsung yang menunjukkan perhatian dan kasih sayang kepada anak-anaknya, dan secara tidak langsung dengan memanfaatkan alat komunikasi. Keamanan, dan perlindungan terhadap anggota keluarga ditunjukkan dengan aturan-aturan yang dimusyawarahkan bersama antar suami dan istri seperti aturan tidak diperbolehkan keluyuran saat Magrib dan tidak boleh 
bermain jauh-jauh baik pada anak perempuan maupun anak laki-laki. Adapun kenyamanan ditunjukkan keluarga dengan aktivitas berkumpul di rumah saat Magrib yang biasanya dilakukan untuk belajar ngaji serta mengulang pelajaran anak di sekolah. Semua responden menjawab bahwa pihak yang paling memiliki kewenangan untuk memberikan perlindungan dalam keluarga adalah laki-laki atau kepala rumah tangga. Belum ditemukan perubahan terkait pemberian kenyamanan, keamanan, perlindungan dan keadilan pada keluarga di Mekarwangi.

Dalam memenuhi fungsi rekreasi, keluarga di masyarakat pedesaan tidak ada yang terlalu memiliki agenda berlibur khusus secara berlebihan, hanya sekedar kualitas waktu berkumpul bersama keluarga, baik di tempat khusus berlibur maupun di rumah, mereka merasa bahwa waktu yang dapat membuat mereka berkumpul melepas rindu dan sejenak beban pekerjaan adalah yang sangat dijunjung dan sangat mereka hargai sebagai fungsi rekreasi keluarga. Temuan juga menujukkan bahwa pada keluarga muda secara berkala (pada musim liburan) mengajak anak-anaknya yang masi kecil ke tempat hiburan jauh dari desa yaitu ke Bandung (kebun binatang dan Trans studio Bandung) atau ke Jakarta (pantai Ancol, Taman mini dan Dunia Fantasi).

Fungsi pemberian status, baik keturunan maupun prestasi masih jarang ditemukan pada keluarga di Desa Mekarwangi. Pada satu kasus, lkeluarga yang memberikan hadiah kepada anaknya karena prestasi di sekolah, namun tidak dilaksanakan setiap mendapatkan prestasi tergantung keadaan ekonominya. Pada suatu waktu ketika keadaan ekonomi memungkinkan untuk memberikan hadiah kepada anaknya maka dilakukan tetapi jika keadaan ekonomi tidak memungkinkan maka tidak dilakukan sehingga fungsi pemberian status/ hadiah pada masyarakat desa mekarwangi bukan merupakan hal yang harus dilakukan.

\section{Perubahan Bentuk dan Struktur Keluarga}

Secara garis besar tipe atau bentuk keluarga terdiri dari keluarga inti dan keluarga luas. Secara umum, struktur keluarga-keluarga di Desa Mekarwangi merupakan keluarga inti yang terdiri dari ayah, ibu dan anak-anak. Pada beberapa kasus keluarga inti ini tidak lengkap karena sebagian anggotanya tidak tinggal serumah karena alasan menuntut ilmu dan bekerja. Demikian juga pada beberapa keluarga luas yang terdiri dari keluarga inti ditambah dengan kakek, nenek dan paman atau bibi. Pada beberapa kasus keluarga tersebut juga mengalami perubahan karena alasan yang sama yaitu meninggal dunia, meninggalkan desa dengan maksud untuk menuntut ilmu dan bekerja, sehingga struktur keluarga luas pun menjadi tidak lengkap. Struktur keluarga tersebut mengalami perubahan namun tidak tetap karena anggota keluarga yang menuntut ilmu dan bekerja pada suatu waktu kembali ke desa. Hal inilah yang disebut dengan perubahan yang tidak permanen.

22 | SOSIOGLLBAL : Jurnal Pemikiran dan Penelitian Sosiologi, Vol. 4, No. I, Desember 2019 
Apabila dianalisis dengan teori fungsional struktural, secara struktur memang terdapat perubahan dalam struktur keluarga karena tidak adanya salah satu atau beberapa anggota keluarga, terdapat beberapa fungsi yang mengalami perubahan yaitu fungsi afeksi dan perlindungan namun fungsi-fungsi tersebut hanya terganggu pada waktu tertentu. Dalam analisis fungsional struktural yang menjadi fokusnya adalah keseimbangan dalam struktur dan fungsi keluarga. Struktur keluarga memang berubah tetapi dalam kenyataannya para responden masih dapat melakukan interaksi dan komunikasi dengan anggota keluarganya yang berada di tempat yang jauh dengan menggunakan alat komunikasi. Dengan lat komunikasi gadget pintar mereka dapat melakukan komunikasi kapan saja dan dimana saja bahkan dapat langsung bertatap muka dengan video call sehingga merasakan kehadiran anggota keluarga padahal sebenarnya berada di tempat yang jauh.

Teori fungsional struktural pada dasarnya menekankan pada keseimbangan sistem dimana suatu sistem dikatakan seimbang apabila sub sistemnya berfungsi. Kajian mengenai struktur keluarga pada masyarakat desa mekarwangi yang mengalami perubahan pada bentuk dan strukturnya dimana struktur keluarga berubah karena anggota keluarga meninggal, meninggalkan desa dengan alasan bekerja dan menuntut ilmu. Berubah strukturnya karena sebagian anggota keluarga tersebut tidak lagi tinggal bersama dengan keluarganya namun dari beberapa kasus yang terdapat pada masyarakat Desa Mekarwangi fungsi keluarganya tidak terganggu karena pada beberapa kasus keluarga inti tidak lengkap dan keluarga luas tidak lengakap, peran ayah yang bekerja jauh dari desa (tidak tinggal bersama) masih berfungsi karena ayah tetap menjadi pemimpin keluarga dimana keputusan-keputusan penting dalam keluarga masih diputuskan oleh ayah demikian juga peran ibu yang bekerja jauh dari desa tetap berfungsi karena ibu masih dapat melakukan komunikasi dengan keluarganya di desa. . Berjalannya fungsi keluarga tersebut juga karena ikatan kekerabatan yang erat antara anggota keluarga dengan keluarga batihnya dan juga keluarga luasnya.

Pada dasarnya teori interaksi simbolik menekankan pada komunikasi antar personal sehingga apabila dianalisis dengan teori interaksi simbolik, bahwa adanya perubahan struktur keluarga pada keluarga di desa mekarwangi yang salah satu anggota keluarganya tinggal jauh dari tempat tinggalnya tetapi masih melakukan interaksi dan komunikasi dengan anggota keluarga yang ditinggalkannya di desa sehingga keberlangsungan keluarga dapat berlangsung karena fungsi keluarga masih dilaksanakan. Masih adanya komunikasi antar anggota keluarga menunjukkan adanya interaksi simbolik. Alat interaksinya adalah bahasa yang bermakna. 


\section{SIMPULAN}

Bentuk, struktur dan fungsi keluarga dalam masyarakat Desa Mekarwangi mengalami perubahan, namun perubahannya tidak permanen. Bentuk keluarganya lebih banyak adalah keluarga inti (nuclear family) dengan strukturnya terdiri dari ayah, ibu dan anak-anak. Pada beberapa kasus struktur keluarga berubah karena ayah atau ibu bekerja di tempat yang jauh dari desa atau anak menuntut ilmu atau bekerja di luar desa. Pada suatu waktu mereka kembali lagi kepada keluarganya, sehingga bentuk atau struktur keluarga berubah namun tidak permanen. Demikian pula fungsi keluarga pada suatu waktu fungsi tertentu tidak dapat dilaksanakan karena salah satu anggota keluarga berada jauh dari tempat tinggal (rumah), namun tidak berlangsung lama bahkan sebenarnya masih dapat dilaksanakan. Misalnya fungsi afeksi dalam keluarga tidak selalu harus dilakukan secara langsung namun juga dapat dilakukan tidak langsung yaitu melalui sarana teknologi atau alat komunikasi. Ungkapan perhatian dapat dilakukan melalui alat komunikasi bahkan dapat dilakukan juga secara intensif karena teknologi komunikasi sekarang ini sudah semakin cepat dan mudah. Dengan demikian perubahan bentuk dan struktur keluarga tidak selalu menimbulkan perubahan fungsi keluarga karena sebagai sistem, keluarga akan melakukan keseimbangan dalam keberlangsungan kehidupan keluarga itu sendiri. Fungsi sub sisem yang tergamggu akan digantikan dengan fungsi sub sistem yang lain dengan peran dan fungsi yang sama.

\section{DAFTAR PUSTAKA}

Anita, R. (2015). Harmoni dalam Keluarga Perempuan Karir : Upaya Mewujudkan Kesetaraan dan Keadilan Gender dalam Keluarga. Palastren, 8(1), 1-34.

Berrington, A., Perelli-Harris, B., \& Trevena, P. (2015). Commitment and the changing sequence of cohabitation, childbearing, and marriage: Insights from qualitative research in the UK. Demographic Research, 33(1), 327-362. https://doi.org/10.4054/DemRes.2015.33.12

Bögels, S. M., \& Brechman-Toussaint, M. L. (2006). Family issues in child anxiety: Attachment, family functioning, parental rearing and beliefs. Clinical Psychology Review, 26(7), 834-856. https://doi.org/10.1016/j.cpr.2005.08.001

Burgess, E., \& Locke, J. (1976). The Family.

Ekasasi, S. R. (2017). The Role of Children in Family Decision Making a Theoretical Review. Jurnal Siasat Bisnis, edisi(khusus), 25-41. https://doi.org/10.20885/jsb.ed.khus1.art3

Fatimah, L. (2010). Hubungan Persepsi Anak terbadap Keharmonisan Keluarga dan Pola Asub Orang Tua dengan Motivasi Belajar (Studi di Prodi D-III Kebidanan FIK UNIPDU Jombang). Universitas Sebelas Maret.

Huinink, J. (2010). Family Research. In German Data Forum (RatSWD (Ed.), Building On Progress (pp. 1041-1056). Germany: Verlag Barbara Budrich, Budrich UniPress.

Ihromi, T. O. (1999). Bunga Rampai sosiologi Keluarga (Pertama; T. O. Ihromi, Ed.). Jakarta: Yayasan Obor Indonesia.

Mansyur, C. M. (1999). Sosiologi masyarakat Desa dan Kota. Surabaya: Usaha Nasional. 
Marotz-baden, A. R., \& Adams, G. R. (2014). What Function Its Its Makes Is Setting Soul Not But a Family The Quality of Interaction Between Parent and Child Is What Determines How a Youngster Grows BY RAMONA MAROTZ-BADEN ,. 1(3), 6-9.

Mizal, B. (2014). Pendidikan Dalam Keluarga. Jurnal Ilmiah Peuradeun, 2(3), 155-178. Retrieved from https://journal.scadindependent.org/index.php/jipeuradeun/article/view/47

Nancy Foner, Kay Deaux, \& Katharine M. Donato. (2018). Introduction: Immigration and Changing Identities. RSF: The Russell Sage Foundation Journal of the Social Sciences, 4(5), 125. https://doi.org/10.7758/rsf.2018.4.5.01

Nasrudin. (2013). Hubungan Fungsi Afektif Keluarga Terhadap Kecerdasan Emosional Remaja. Jurnal Edu Health, 3(2), 97-102.

Puspitawati, H. (2013). Konsep dan Teori Keluarga. Komunikasi Pembangunan, Vol. 4, pp. 1-16. https://doi.org/10.1249/01.mss.0000074580.79648.9d

Rochaniningsih, N. S. (2014). Dampak Pergeseran Peran Dan Fungsi Keluarga Pada Perilaku Menyimpang Remaja. Jurnal Pembangunan Pendidikan: Fondasi Dan Aplikasi, 2(1), 59-71. https://doi.org/10.21831/jppfa.v2i1.2618

Rustina. (2014). Kekuarga dalam kajian Sosiologi. Musawa, 6(2), 287-322.

Salviana, V., \& Sugiarti. (1994). Distribusi dan alokasi kekuasaan dalam keluarga. Bestari, 16, 24-28.

Shukla, A. (2015). Changes in the Nature of Family Relationships in the Contexts of a Critical Analysis of Definitions of Family in Literature and the Changes in the Nature of Family Relationships in the Contexts of Urbanization and. Reasearch Gate.

Sobotka, T., \& Toulemon, L. (2008). Overview Chapter 4: Changing family and partnership behaviour. Demographic Research, 19(6), 85-138. https://doi.org/10.4054/demres.2008.19.6

Soeradi. (2013). Perubahan sosial dan ketahanan keluarga : meretas kebijakan berbasis kekuatan lokal. Informasi, 18(02), 83-94. Retrieved from http://puslit.kemsos.go.id/upload/post/files/7c7215558ab75901046e1db2065ed013. pdf

Sutikno, E. (2014). Hubungan Fungsi Keluarga dengan Kualitas Hidup Lansia. Universitas Sebelas Maret.

Utami, N. (2017). Pengalaman Komunikasi Keluarga Istri Yang Berpendapatan Lebih Besar Dari Suami. Jurnal Kajian Komunikasi, 4(1), 95-108. https://doi.org/10.24198/jkk.vol4n1.9

Utamidewi, W., Mulyana, D., \& Rizal, E. (2017). Pengalaman Komunikasi Keluarga Pada Mantan Buruh Migran Perempuan. Jurnal Kajian Komunikasi, 5(1), 69-80. https://doi.org/10.24198/jkk.v5i1.7901

White, A., Grabowska, I., Kaczmarczyk, P., \& Slany, K. (2018). Family relations and gender equality in the context of migration. UCL Press, 108-130. https://doi.org/10.2307/j.ctv550d7m.10

Wirdhana, I., Muin, Edi., Windrawati, W., Hendardi, A., Nuranti, A., Trihantoro, D., Angkawijaya, A., Isyanah, A., Suparyati, R., Marifah, K., Kusumastuti, I., Suharno, R., Soetriningsih., Zuhdi, A., Setiadi, E., Susilo, P. (2013). Buku Pegangan Kader BKR Tentang Delapan Fungsi Keluarga (Pertama). Retrieved from http://docplayer.info/30920851-Buku-pegangan-kader-bkr.html

Yulion, M. M., Lestari, S. B., \& Rakhmad, W. N. (2013). Memahami pengalaman komunikasi pengasuhan anak dalam extended family. Jurnal Universitas Diponegoro, 2, 1-39.

Zorn, J. G. (2010). Custom then and now: the changing Melanesian family. ANU Press, 93124. 